\title{
A Musty "Off" Flavor in Nova Scotia Potatoes Is Associated with 2,4,6-Trichloroanisole Released from Pesticide-treated Soils and High Soil Temperature
}

\author{
Barbara J. Daniels-Lake ${ }^{1}$, Robert K. Prange, Sonia O. Gaul, Kenneth B. McRae, and \\ Roberto de Antueno \\ Agriculture and Agri-Food Canada, Atlantic Food and Horticulture Research Centre, 32 Main Street, \\ Kentville, N.S. B4N 1J5, Canada \\ David McLachlan \\ Canadian Food Inspection Agency, 1992 Agency Drive, Dartmouth, N.S. B2Y 3Z7, Canada
}

\begin{abstract}
AdDitional Index wORDs. benzene hexachloride, chlorothalonil, chlorpyrifos, gamma cyclohexane hexachloride, fludioxonil, imidacloprid, linuron, TCA, Solanum tuberosum

Abstract. In Fall 2001 in Nova Scotia's Annapolis Valley (Canada), several million kilograms of processing and tablestock potatoes (Solanum tuberosum L.) were affected by a severe "musty" "off" flavor and "off" odor that persisted after cooking. 2,4,6-Trichloroanisole (TCA), a potent musty flavor/odor compound that is not known to be a potato metabolite was detected in samples of three potato lots rejected by consumers. To determine the role and source of TCA in the affected crop, samples of tubers from 30 fields were evaluated, including examination of production inputs and industry estimation of the "off" flavor, expert organoleptic assessment of flavor-odor intensity, and analytical quantitation of the TCA content of affected tubers, followed by a soil challenge to provoke TCA production. Production of "musty" potatoes was associated with unusually hot $\left(>30{ }^{\circ} \mathrm{C}\right)$ soil temperatures during the 2001 growing season, and in some cases with $\gamma$-cyclohexane hexachloride (CHC) applied to control soil wireworm (putatively Limonius agonus Say). TCA quantitation and organoleptic assessment were in general agreement. Samples of soils from "idle" fields (no agricultural inputs for at least 8 years) and "production" fields (produced "off"-flavor potatoes in 2001) were subjected to several factors: 1) presence or absence of potato tubers; 2) preheating at $30{ }^{\circ} \mathrm{C}$ for 3 days, or no preheating; and followed by 3 ) no pesticides, or $\gamma$-CHC, chlorothalonil, chlorpyrifos, fludioxonil, imidacloprid, or linuron applied singly, or all six pesticides applied together. After incubation for 2 weeks at $22{ }^{\circ} \mathrm{C}$ day $/ 14{ }^{\circ} \mathrm{C}$ night with a 14-hour photoperiod, solid-phase microextraction/gas chromatographic-mass spectrometric analysis revealed that untreated soils released small quantities of TCA $\left(2.8 \mathrm{~mol} \cdot \mathrm{kg}^{-1}\right)$ whereas higher quantities of TCA were present in soils treated with pesticides $\left(3.8-6.6 \mathrm{~mol} \cdot \mathrm{kg}^{-1}\right)$. The quantity of TCA released was not significantly affected by the presence or absence of potato tubers, but it was increased by preheating the soil sample, regardless of the other two factors, and by an interaction between pesticides and soil source. The quantity of TCA from both "idle" and "production" soils was highest when $\gamma$-CHC was added alone $(214 \%$ and $284 \%$ of checks respectively). TCA production increased in the presence of the other five pesticides applied singly in "production" soils, but not in "idle" soils. Application of the six pesticides together increased TCA in both soils. Such an association of TCA-based "musty" "off" flavor with field soils containing $\gamma$-CHC and other pesticides combined with high soil temperature had not been reported previously.
\end{abstract}

In 2001, several million kilograms of fresh and processed potato products from the Annapolis Valley of Nova Scotia, Canada (i.e., most of the local crop) was rejected by consumers because of a strong "musty" "off" flavor and odor (OFO). As a consequence, all the locally processed potato products were voluntarily withdrawn from the retail market and potatoes in storage were rejected by a local processor. The growers' loss of revenue for most of the year's production threatened the survival of the Nova Scotia potato industry.

Several strongly flavored compounds are known to occur naturally in low concentrations in potatoes (Coleman et al.,

Received for publication 20 Mar. 2006. Accepted for publication 28 Sept. 2006. Contribution no. 2317, Atlantic Food and Horticulture Research Centre, Agriculture and Agri-Food Canada.

We thank D.M. Nash for chemical analysis and Drs. J. Delong and K. Pruski for internal review of the manuscript.

${ }^{1}$ Corresponding author. E-mail: DanielsLakeB@agr.gc.ca
1981; Mazza and Pietrzak, 1990; Nursten and Sheen, 1974) and some of these may be described as "musty." A preliminary gas chromatographic-mass spectrometric (GC-MS) analysis of three OFO-affected potato samples indicated the presence of several "off-flavor" compounds, including 2,4,6-trichloroanisole (TCA), 2-methyl-isoborneol, and geosmin (P. Silk, personal communication) that are not naturally produced by potato tubers (Buttery and Ling, 1973; Buttery et al., 1970; Coleman et al., 1981).

Objectionable musty or earthy flavors and odors occasionally affect various food commodities and can cause the product to be rejected by consumers. Many compounds are associated with "musty" "off" flavors in the food industry, including the three noted here. Among these, TCA is considered the most potent; it is one of several chloroanisoles and chlorophenols that are very often responsible for OFO in foods (Maarse et al., 1988; Nijssen, 1991). Since it was first associated with "off"-flavor problems in broiler chickens in 1974 (Land 
et al., 1975), off-flavor problems in various other food and beverage products have been linked to TCA [e.g., "corkiness" in wine (Busser et al., 1982), "Rio" flavor in coffee (Liardon et al., 1990; Spadone et al., 1990), and "musty" flavors in dried fruit (Aung et al., 1996; Tindale, 1987; Whitfield et al., 1985) and pastries (Maarse et al., 1988)]. The majority of the reported occurrences of TCA-based "musty" "off" flavor in foods have been associated with postharvest contamination. Introduction of TCA into foods of plant origin before harvest has not been reported previously. TCA can be produced by many species of ubiquitous, nonpathogenic microorganisms, especially fungi (Curtis et al., 1974; Hill et al., 1995). Adapted strains of these organisms can convert precursors such as chlorophenols or cyclohexane hexachloride to TCA (Engst et al., 1977; Maarse, et al., 1988; Neidleman and Geigert, 1986; Tindale et al., 1989).

Potato production information from the affected Nova Scotia growers was examined, and government and industry authorities in other potato-growing areas, especially in nearby Prince Edward Island and New Brunswick, Canada, were consulted. This off flavor problem affected eight cultivars and was reported only in Nova Scotia. One factor associated solely with Nova Scotia was the application of the insecticide $\gamma$-CHC [Lindane 25WP (25\% a.i.); Plant Products, Brampton, Ont., Canada] to many Annapolis Valley, Nova Scotia, potato fields in 2001. The $\gamma$-CHC was applied before planting according to the pesticide label recommendation, to control an exceptional outbreak of wireworm that had seriously damaged the potato crop in previous years. The association of OFO with $\gamma$-CHC was not definitive, however, because 5 of the 13 potato samples most severely affected by OFO were grown in fields that did not receive $\gamma$-CHC, although other pesticides had been applied.

Soon after its introduction as an insecticide in the late 1940s, $\mathrm{CHC}$ [originally referred to as benzene hexachloride (BHC)] was associated with off-flavor problems in root and tuber crops (Greenwood and Tice, 1949). However, research at the time attributed these problems to the presence of "non- $\gamma$ isomers of BHC" [i.e., non- $\gamma$ isomers of CHC (Dawson et al., 1953; Elvers et al., 1985)], and a commercial product comprised of the $\gamma$-isomer alone (Lindane) was developed (I. Schmidt, pers. comm.). No association with TCA was made at that time, because the early reports of "BHC" -based "off" flavors predate the research on TCA-based "off" flavors by two decades. However, TCA is now recognized as one of many known products of microbial degradation of some pesticides, including $\gamma$-CHC (Engst et al., 1977; Maarse et al., 1988; Whitfield, 1986).

Chemical analysis of three severely OFO-affected lots of Annapolis Valley, Nova Scotia, potatoes in 2001 showed that the $\gamma$-CHC residues were all less than the maximum allowable level of $0.34 \mathrm{~mol} \cdot \mathrm{kg}^{-1}$ (Canadian Food Inspection Agency, unpublished) (Health Canada, 2005), and therefore also less than the organoleptic threshold of $\approx 0.4$ to $1 \mathrm{~mol} \cdot \mathrm{kg}^{-1}$ (Dawson et al., 1953; Reynolds et al., 1953; Wolfenbarger et al., 1948). Analysis of the commercial product used confirmed that it contained $99 \% \gamma-\mathrm{CHC}$, in agreement with the package label (S. Gaul, unpublished). Therefore, the OFO was considered unlikely to be attributable to non- $\gamma$ CHC isomers.

Evaluation of the production methods and inputs applied during the 1999, 2000, and 2001 production seasons to 38 fields that produced potatoes in 2001 judged by industry to have various amounts of OFO revealed that 1) production methods were typical of those used throughout North America; 2) production inputs were applied according to recommended methods; 3) 8 of 13 tuber samples judged by industry to have severe OFO were grown in fields treated with $\gamma$-CHC to control wireworm, including the three most severely affected samples; 4) the weather during the 2001 growing season was unusually hot and dry, and was the fourth droughty year in a 5-year period; and 5) associations with other factors were not apparent.

Based on these field observations, a study was conducted to assess and define further factors that may have contributed to the OFO in Nova Scotian potato tubers. Laboratory, economic, and time constraints limited instrumental analysis to a single compound (i.e., TCA). Samples of tubers from 30 fields were collected and analyzed to determine their TCA content. Subsamples were rated organoleptically by a trained sensory panel of product experts. The correlation between the sensory panel scores and TCA content was assessed and cross-referenced with the industry rankings of OFO and whether $\gamma$-CHC had been applied to the field source of each tuber sample. A laboratory study was initiated to determine whether there was a link between the addition of selected pesticides to Nova Scotia potato fields and the presence of TCA in those soils.

\section{Materials and Methods}

ASSEMbly of AFFeCted potato material AND INDUSTRY SENSORY RATINGS. Thirty samples of tubers were assembled for evaluation. One control sample was drawn from research material unaffected by OFO (as judged by the authors), grown in the Annapolis Valley, Nova Scotia, on a commercial field that had not been treated with $\gamma$-CHC. The remaining 29 were samples of commercially produced potatoes that had been judged by the local potato industry to have a range of commercial acceptability in relation to OFO. The commercial potatoes or processed products made from them had been rated by industry on three or more occasions, using a 1 to 10-point scale based on a descriptive range of "OK, good" through "terrible, unacceptable for use." However the criteria for these assessments and assignment of the ratings were not clearly defined. To facilitate evaluation of this information, the samples were subdivided into four categories (unacceptable, poor, fair, and good), which indicated at least one industry rating of 10 points, industry ratings of 5 to 9 points inclusive, industry ratings of 2 to 4 points inclusive, and ratings of 1 point in all industry tests respectively.

EXPert SENSORY ANALysis. Because the criteria for the industry sensory ratings were not well defined, professional organoleptic evaluation of tubers was carried out by a sensory panel of product expert assessors [as defined by Reilly and York (2001)] specifically trained in taint recognition at the Canadian Food Inspection Agency (Dartmouth, N.S., Canada). The taste, odor, and relative intensity of number-coded samples of raw tubers and processed potato products were evaluated by three product experts specifically trained in the recognition of TCA OFO (International Organization for Standardization, 1993; Reilly and York, 2001). Each sample was rated independently by each tester on three separate occasions, using a scale of 0 to 100 points, where a score of 0 point indicated no detectable TCA-like OFO and 100 points was equivalent to the OFO of $473 \mathrm{~mol} \cdot \mathrm{kg}^{-1} \mathrm{TCA}$ in United States Pharmacopeia (USP)-grade odorless mineral oil.

In addition to the expert sensory analysis, 11 samples (which represented the range of OFO found in the sensory analysis) were selected for assessment using gas chromatography/olfactometry 
(GC/O) to determine the specific chemicals responsible for the musty odor. The volatiles in a large volume $(800 \mathrm{~mL})$ of head space from samples ( $40 \mathrm{~g}$ diced raw potato) were captured at room temperature on Tenax cartridges $(6 \mathrm{~mm}$ o.d., $4 \mathrm{~mm}$ i.d. $\times$ 115 mm, Tenax TA; Supelco Canada, Oakville, Ont., Canada) and thermally desorbed into the GC, using a Dynatherm 890 Thermal Desorption Unit (CDS Analytical, Oxford, Pa.), with a $50 \mathrm{~cm} \times 0.53 \mathrm{~mm}$ i.d. uncoated quartz column tubing transfer line inside a heated stainless steel jacket at $120^{\circ} \mathrm{C}$, with a desorption temperature of 20 to $180{ }^{\circ} \mathrm{C}$ in $15 \mathrm{~s}$ and held for $5 \mathrm{~min}$, and a desorption flow rate of $10 \mathrm{~mL} \cdot \mathrm{min}^{-1}$. The transfer line connected directly to an Innowax $30 \mathrm{~m} \times 0.53 \mathrm{~mm}$ column (Agilent Technologies, Santa Clara, Calif.) inside a modified Varian 3400 GC (Varian Canada, Mississauga, Ont., Canada), held at $34{ }^{\circ} \mathrm{C}$ for $5 \mathrm{~min}$, increased at $10{ }^{\circ} \mathrm{C} \cdot \mathrm{min}^{-1}$ to $150{ }^{\circ} \mathrm{C}$, increased $20{ }^{\circ} \mathrm{C} \cdot \mathrm{min}^{-1}$ to $180{ }^{\circ} \mathrm{C}$, held for $1.90 \mathrm{~min}$, with a flow rate of $10.0 \mathrm{~mL} \cdot \mathrm{min}^{-1}$, carrier $\mathrm{N}_{2}$, and a total chromatographic run time of $20.0 \mathrm{~min}$. At the column outlet, one half of the eluent was directed to a $32 \times 50-\mathrm{mm}$ glass olfactory nosepiece, with $2 \mathrm{~L} \cdot \mathrm{min}^{-1}$ humidified air makeup gas added at the base of the nosepiece.

Odor profiles and odor intensity of the volatiles were recorded by an expert sensory analyst trained as an olfactometry detector for $\mathrm{GC} / \mathrm{O}$. The other half of the eluent was directed through a Varian flame ionization detector held at $150{ }^{\circ} \mathrm{C}$. The dual channel signals were simultaneously processed using Varian Star Chromatography Workstation software (version 5.51; Varian Canada). These results were compared with a parallel chromatographic analysis on the head space of a $473 \mathrm{~mol} \cdot \mathrm{kg}^{-1}$ TCA standard dissolved in USP mineral oil using the same instrument and conditions described earlier.

Soil Challenge. Controlled laboratory experiments were conducted to assess the effect of soil source, temperature, presence or absence of potato tubers, and selected pesticides on TCA volatile production.

Because TCA consists of an aromatic ring with three chlorine atoms (Fig. 1), the chemical structures of all pesticides used on the investigated potato fields in 1999, 2000, and 2001 were reviewed to identify the presence of chlorine or aromatic ring structures, because these could represent precursors for conversion to TCA (Engst et al., 1977; Neidleman and Geigert, 1986). Pesticides that had been added to the production regime within the past 2 years were also identified as potentially problematic. Based on these criteria, $\gamma$-CHC, chlorothalonil [Bravo 500 Liq. (500 g. $\mathrm{L}^{-1}$ a.i.); Syngenta Crop Protection<smiles>COc1c(Cl)cc(Cl)cc1Cl</smiles>

$\mathbf{E}$<smiles>CON(C)C(=O)Nc1ccc(Cl)c(Cl)c1</smiles>

B

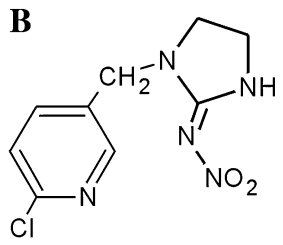

$\mathbf{F}$

<smiles>N#Cc1c(Cl)c(Cl)c(Cl)c(Cl)c1C#N</smiles>

D<smiles>ClC1C(Cl)C(Cl)C(Cl)C(Cl)C1Cl</smiles><smiles>N#Cc1c[nH]cc1-c1cccc2c1OC(F)(F)O2</smiles>

Fig. 1. Chemical structure of (A) 2,4,6-trichloroanisole, (B) imidacloprid, (C) chlorothalonil, (D) cyclohexane hexachloride, (E) linuron, (F) chlorpyrifos, and (G) fludioxonil.
Canada, Guelph, Ont., Canada], chlorpyrifos [Lorsban 4E (480 g. $\mathrm{L}^{-1}$ a.i.); Dow AgroSciences, Calgary, Alta., Canada], fludioxonil [Maxim PSP $0.5 \%$ dust (0.5\% a.i.); Novartis Crop Protection Canada, Guelph, Ont., Canada], imidacloprid [Admire 240FS (240 g. $\mathrm{L}^{-1}$ a.i.); Bayer CropScience, Calgary, Alta., Canada] and linuron [Lorox 50DF (50\% a.i.); E.I. duPont Canada Co., Mississauga, Ont., Canada] were selected for soil challenge testing (Fig. 1). It was hypothesized that the naturally occurring soil microorganisms may have used one or more of these compounds to produce TCA under the unusually hot and dry growing conditions in 2001 .

Samples of field soils from four different sites were collected in late Jan. 2002 by gathering topsoil to a depth of $\approx 15 \mathrm{~cm}$ using a farm tractor equipped with a front-end loader. Sufficient soil to fill a wooden bulk bin (interior dimensions, $118 \times 105 \times$ $55 \mathrm{~cm}$; constructed locally) lined with plastic film was collected from each site. The soils were thawed, the excess water was allowed to drain, and they were air-dried for several weeks in a greenhouse (15 to $20{ }^{\circ} \mathrm{C}$, ambient light) until the moisture content was suitable for handling. Two of the soils were from Atlantic Food and Horticulture Research Center field sites that had no agricultural inputs for at least 8 years ["idle" soils, a "Berwick" moderately well-drained loam or sandy loam soil, and a "Canning" well-drained sandy loam or loamy sand soil (Langille, 1986)] and two soils were from commercial potato fields that had produced potatoes judged by industry sensory evaluation to have "unacceptable" OFO ["production" soils, a "Truro" well-drained fine sandy soil (Langille et al., 1993), and a "Debert" imperfectly drained coarse-loamy soil (Holmstrom and Thompson, 1989)]. Both "production" soils had been treated with $\gamma-\mathrm{CHC}$ at the beginning of the 2001 growing season.

The soil content of each bin was thoroughly mixed before samples for the soil challenge were taken. Each pesticide was added individually to a 4 - $\mathrm{L}$ wide-mouth glass jar containing $\approx 3 \mathrm{~L}$ of one of the four soils. Application of pesticides followed the recommendations on the product label for potato production, adjusted to the soil surface area in the jars. The required quantity of each pesticide was thoroughly mixed into $\approx 0.25 \mathrm{~L}$ of the appropriate soil, and the amended soil was spread over the surface of the soil already in the jar. A combined treatment was also used, in which all six pesticides were added to the additional $0.25 \mathrm{~L}$ of soil. Control jars of each of the four soils, to which no pesticides were added to the additional $0.25 \mathrm{~L}$ of soil, were also prepared. The soil challenge trial was conducted four times, providing four replicates of each pesticide $\times$ soil combination, and eight replicates for each pesticide $\times$ soil type combination.

Three small potato tubers $(25-$ 50 g, new-crop 'LA Chipper' potatoes imported from Florida and purchased from a local market) were partially buried in the upper portion of the soil in half the jars, and half the jars were preheated at $30{ }^{\circ} \mathrm{C}$ for $3 \mathrm{~d}$. The jars were then incubated in a growth chamber (model GR36; Enconaire, Winnipeg, Man., Canada) at $22{ }^{\circ} \mathrm{C}$ day/ $18{ }^{\circ} \mathrm{C}$ night, $14-\mathrm{h}$ photoperiod, for 2 weeks. All jars were left uncovered during preheating and incubation. Each jar received $100 \mathrm{~mL}$ 
distilled water at the start of the trial, and at weekly intervals thereafter, which approximated droughty field conditions in all jars. Jars were checked daily and any weeds that germinated in the jars were removed regularly. After incubation, the TCA content of all soils were evaluated by solid-phase microextraction (SPME)/GC-MS, as described later.

The four soil challenge trials were divided into two sets of two consecutive trials, and the sets were conducted 5 weeks apart. Within each trial, the start date was staggered over 4 consecutive days according to the statistical design, to permit timely laboratory analysis. Eight jars of soil commenced the preheating phase each day, progressed to incubation after $3 \mathrm{~d}$, and subsequently were analyzed on the same day after the incubation period ended. Soil samples from trials 1 and 2 were analyzed immediately. However, because of funding limitations and the loss of access to the analytical equipment and technical expertise used to analyze trials 1 and 2, the soil samples from trials 3 and 4 were frozen and analyzed at a later date in a different laboratory using a slightly different method.

TCA AnALYSIS. The TCA content of the 30 assembled tuber samples and the TCA released from samples of soil from the soil challenge trials after the end of the incubation period were quantified analytically as described below.

Tuber ANALYSIS. The TCA content of the 29 commercial potato samples and the control sample was determined analytically by SPME/GC-MS of a subsample of tubers. Two portions of the tubers were sampled. For the skin tissue, the tuber surface was sampled to a depth of $\approx 2 \mathrm{~mm}$, which included the periderm and underlying cortex. The internal tissue was sampled a minimum of $15 \mathrm{~mm}$ below the original unpeeled surface of the tuber. The tissue samples were chopped finely by hand with a knife on a glass plate into $\approx 2 \times 2 \times 3$-mm fragments, $12 \mathrm{~g}$ of tissue was weighed into a $43-\mathrm{mL}$ amber glass vial with a Teflonseptum cap, and $25 \mathrm{~mL}$ of high-purity water (MilliQ UF PLUS; Millipore (Canada) Ltd., Mississauga, Ont., Canada) was added. Heating, SPME exposure, and TCA quantitative analysis was as described in "Analysis Method 1."

Analysis Method 1. The analysis of the soil samples from trials 1 and 2, and the analysis of tuber tissue were based on Supelco application note 147 (Supelco, 1998) and were similar to the method of Evans et al. (1997). After incubation, the jars of soil were loosely covered with metal lids and held at $9{ }^{\circ} \mathrm{C}$ in darkness for 24 to $72 \mathrm{~h}$ until analysis. A 29-g sample of soil was weighed into a $43-\mathrm{mL}$ amber glass vial with a Teflon-septum cap and heated in a water bath for $20 \mathrm{~min}$ at $70{ }^{\circ} \mathrm{C}$, with sonication for the last $5 \mathrm{~min}$. The sample was shaken vigorously by hand and returned to the water bath for $5 \mathrm{~min}$. A SPME fiber ( $2 \mathrm{~cm} 50 / 30 \mu \mathrm{m}$ divinylbenzene/carboxen on polydimethylsiloxane, StableFlex; Supelco, Bellefonte, Pa.) was inserted through the septum and exposed in the head space of the vial for $30 \mathrm{~min}$ at $70{ }^{\circ} \mathrm{C}$. The fiber was desorbed into the injector of the GC (model 3400; Varian Canada) equipped with a $30 \mathrm{~m} \times 0.25-\mathrm{mm}$ DB-5MS glass capillary column with a $0.25 \mu \mathrm{m}$ stationary phase (J\&W Scientific, Folsom, Calif.) He carrier gas at $1.0 \mathrm{~mL} \cdot \mathrm{min}^{-1}$ with an injector temperature of $250{ }^{\circ} \mathrm{C}$ and a column temperature program as follows: $50{ }^{\circ} \mathrm{C}$ for $5 \mathrm{~min}$, increased $6^{\circ} \mathrm{C} \cdot \mathrm{min}^{-1}$ to $140{ }^{\circ} \mathrm{C}$, increased $10{ }^{\circ} \mathrm{C} \cdot \mathrm{min}^{-1}$ to $260{ }^{\circ} \mathrm{C}$ and held at $260{ }^{\circ} \mathrm{C}$ for $3 \mathrm{~min}$. A transfer line maintained at $220^{\circ} \mathrm{C}$ coupled the $\mathrm{GC}$ to an MS (Finnigan MAT Magnum; Thermo Electron Corp., Waltham, Mass.) with a detector temperature of $220^{\circ} \mathrm{C}$, a scan rate of $1 \mathrm{~Hz}$, and an electron ionization detection mode with automatic gain control and filament current at $100 \mu \mathrm{A}$.
The mass range scanned was 195 to 216 atomic mass units (amu). The spectrum of each sample was analyzed using the Magnum Data Base and the Automated Mass Spectral Deconvolution and Identification System [AMDIS version 2.1; National Institute of Standards (NIST), Gaithersburg, Md.] and the NIST Spectrum Search program (version 1.7A). Integration was performed manually to correct the baseline of each peak.

Selected ion monitoring (ion profile at 195 and $210 \mathrm{amu}$ ) was used to identify the compound, and the total area count of all ions (mass range, 195-216 amu) was used to quantify the data. Presence of TCA was confirmed and quantified by comparison with $118 \mathrm{~mol} \cdot \mathrm{kg}^{-1}$ TCA (Chemical Abstracts Service (CAS) 87-40-1; 99\%; Supelco) aqueous standard, and by analysis of the mass spectrum of each sample by GC-MS using the Magnum Data Base, AMDIS (version 2.1) and the NIST Spectrum Search program (version 1.7A).

AnAlysis Method 2. Soil samples from trials 3 and 4 were stored at $-40{ }^{\circ} \mathrm{C}$ until analysis. The frozen samples were transferred to $\mathrm{a}-20{ }^{\circ} \mathrm{C}$ freezer during the analysis period. Samples to be analyzed each day were maintained at $-4{ }^{\circ} \mathrm{C}$ overnight and then at $22{ }^{\circ} \mathrm{C}$ for $1 \mathrm{~h}$ before analysis. Soil samples were extracted and analyzed using a method based on the methods of Alzaga et al. (2003), Evans et al. (1997) and Riu et al. (2002), and similar to Ezquerro and Tena (2005). A 10-g sample of soil, or TCA standard solution, was weighed into a $43-\mathrm{mL}$ glass vial. The vial was covered with aluminum foil and placed in a $70^{\circ} \mathrm{C}$ water bath. An SPME fiber was inserted through the foil and was exposed to the head space atmosphere over the soil (or above the TCA aqueous standard solution) for $60 \mathrm{~min}$.

After TCA was identified by MS using an $6890 \mathrm{~N}$ GC system equipped with a 5973 inert quadrupole MS detector (Agilent Technologies) with a split/splitless injector, TCA concentration was determined using an HP 5890A GC (Hewlett-Packard, Palo Alto, Calif.) with an electron capture detector [ECD (HP Ni-63; Hewlett-Packard)] held at $300{ }^{\circ} \mathrm{C}$, which provided greater analytical precision compared with the MS detector. A megabore column, HP50+ $(30 \mathrm{~m} \times 0.53 \mathrm{~mm} \times 0.5 \mathrm{~m}$; Agilent Technologies) was used with 95 argon: 5 methane (v/v) as carrier gas $\left(2.4 \mathrm{~mL} \cdot \mathrm{min}^{-1}\right)$ and makeup gas to a total of $30 \mathrm{~mL} \cdot \mathrm{min}^{-1}$.

The SPME fiber was removed from the sample vial, injected directly into the ECD-equipped GC with the injector port maintained at $250{ }^{\circ} \mathrm{C}$, and removed after $5 \mathrm{~min}$. The GC oven temperature program was $75^{\circ} \mathrm{C}$ for $3 \mathrm{~min}$, increased to $180^{\circ} \mathrm{C}$ at $6{ }^{\circ} \mathrm{C} \cdot \mathrm{min}^{-1}$, held $1 \mathrm{~min}$ at $180{ }^{\circ} \mathrm{C}$, then increased to $250{ }^{\circ} \mathrm{C}$ at $14{ }^{\circ} \mathrm{C} \cdot \mathrm{min}^{-1}$ and held at $250^{\circ} \mathrm{C}$ for $1 \mathrm{~min}$. The total run time using these conditions was $27.5 \mathrm{~min}$, and the retention time of TCA was $10.0 \mathrm{~min}$. Data were collected and analyzed using ChemStation software (revision A.03.02, 23 Mar. 1999; ChemStation, Dayton, Ohio).

The concentration of TCA was determined using an external 5-point calibration with TCA standard (99\%; Aldrich, Oakville, Ont., Canada). TCA was dissolved in hexane (stock solution), then diluted with methanol; the working standards were prepared in water. The limit of detection was determined to be $14 \mathrm{~mol} \cdot \mathrm{kg}^{-1}$ (twice the background).

EXPERIMENTAL DESIGN AND DATA ANALYSIS. Regression analysis using GenStat 5 statistical software (Payne, 2005) was used to analyze the relationship between the TCA content of tuber skin and the organoleptic ratings.

The statistical design for the soil challenge experimental series was a confounded fractional factorial design (four 
one-quarter fractions) laid out in a split-split plot arrangement with eight main plots (four trials with two 2-d blocks), 2 consecutive days within each block, and eight samples per day for a total of 128 experimental units. Each analysis method had four main plots, to which the four combinations of preheating (or not) and addition of potato tubers (or not) were randomized. Each 2-d block had 16 samples split into eight samples evaluated per day; the eight pesticide treatments were evaluated each day, but their interaction with soil type was confounded between days within the 2-d block in a balanced pattern according to the fractional design.

The TCA data were transformed to $\log _{10}$ values before statistical analysis to normalize the distribution. A generalized analysis of variance (ANOVA) using GenStat 5 statistical software (Payne, 2005) was used to analyze the data and to partition the sources of variation according to the design and the fixed experimental factors. Statistical diagnostics were used to assess the adequacy of the ANOVA model. Fixed effects for the analysis were the analysis method, soil type, preheating, potato tuber addition, pesticides, and interactions among the experimental factors. Random effects included fields within each soil type, laboratory replicates (main plots), 2-d blocks, and days within replicates. Unless noted otherwise, only results significant at $P \leq 0.05$ are discussed.

\section{Results and Discussion}

The concentration of TCA was found to be more than 10 -fold higher in the skin (outer $2 \mathrm{~mm}$ ) than in the central tissue of the potato tubers $\left(0.5 \pm 0.6 \mathrm{~mol} \cdot \mathrm{g}^{-1}\right.$ vs. $0.04 \pm 0.03 \mathrm{~mol} \cdot \mathrm{g}^{-1}$ respectively; R. de Antueno, B.J. Daniels-Lake, and R.K. Prange, unpublished), suggesting that the source of TCA was in the soil or that TCA production occurred in the potato skin. The odor identified as "musty" from the potatoes in the $\mathrm{GC} / \mathrm{O}$ analysis had the same retention time (16.5 $\mathrm{min})$ and odor character as the TCA in oil reference analysis (D. McLachlan, unpublished data). Because the major focus was on TCA, the specific chemical identities of the 22 other compounds detected in the $\mathrm{GC} / \mathrm{O}$ analysis, including five identified as "musty" or "earthy" odors, were not determined. They may have included other chloroanisoles, or other compounds known to cause "musty" or "earthy" odors.

The TCA content of tuber skin and the expert sensory scores of the 30 tuber samples were in general agreement with the corresponding industry ratings (Fig. 2). Samples that had the highest TCA content tended to be scored by the expert panel as having the strongest "musty" character among the samples tested. In general, the expert sensory scores increased by $12 \mathrm{U}$ (SE, 1.9) with each unit increase in $\log _{10} \mathrm{~mol} \cdot \mathrm{kg}^{-1} \mathrm{TCA}$. Three samples from $\gamma$-CHC-treated fields had both the three highest expert sensory scores and the highest skin TCA contents (Fig. 2 ). However, some samples grown without $\gamma$-CHC had relatively high expert sensory scores (i.e., strong OFO) and were rated either "poor" or "unacceptable" by industry. This may have been attributable to the presence of one or more OFO compounds other than TCA. Interestingly, other tuber samples grown without $\gamma-\mathrm{CHC}$ and with both low TCA from tuber skin and low (i.e., good) expert sensory scores had been rated "poor" or "unacceptable" by industry (Fig. 2). This suggests that factors in addition to field application of $\gamma$-CHC may have influenced the perceived quality, and therefore the industry rating, of these tubers. For example, "fatigue" and "carryover"

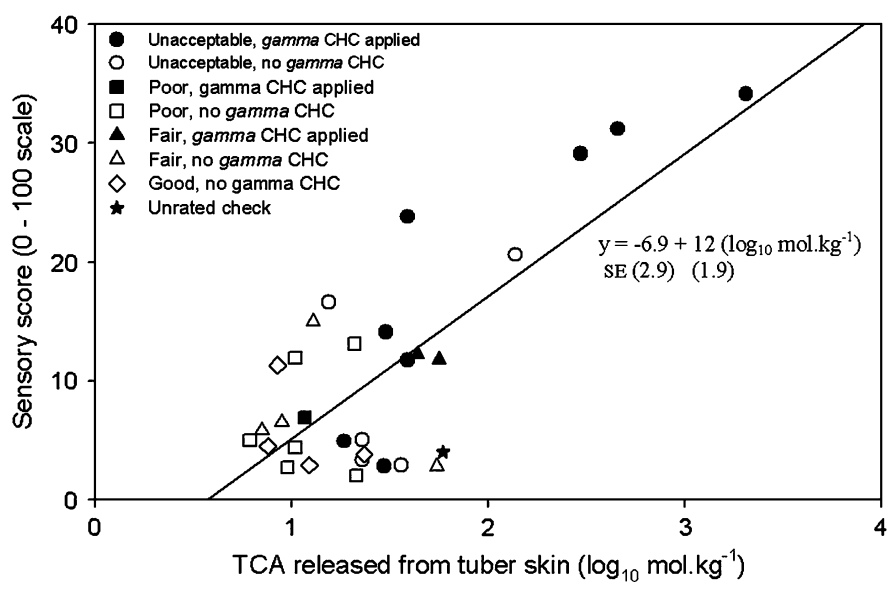

Fig. 2. Linear regression of expert sensory data versus 2,4,6-trichloroanisole (TCA) released from the skin of potato tubers from 29 commercial fields and one control sample. Expert sensory scores are based on a scale of 0 to 100 points, where higher scores indicate stronger "musty" character and the maximum score is equivalent to the "off" flavor/ "off" odor of $473 \mathrm{~mol} \cdot \mathrm{kg}^{-1}$ TCA in odorless mineral oil. Application of $\gamma$-cyclohexane hexachloride $(\gamma-\mathrm{CHC})$ to the fields before potato production is indicated by filled symbols; open symbols indicate tubers produced without $\gamma$-CHC. Acceptability groupings of tuber samples, based on industry-defined sensory ratings of 1 to 10 points ("good" to "unacceptable" respectively) performed a minimum of three times, are defined as follows: unacceptable includes samples that were rated 10 points on one or more occasions, poor includes samples rated from 5 to 9 points, fair includes samples rated from 2 to 4 points, and good includes samples rated 1 point on all industry test occasions.

of TCA taste from one sample to the next, variability among numerous testers, environmental influences, and the presence of other taste or odor compounds can influence the organoleptic perception of TCA (Frijters and Bemelmans, 1977; Griffiths, 1974; Guadagni et al., 1963; Maarse et al., 1988). "Carryover" is the persistence of the taste and odor of TCA, and contributes TCA taste or odor to unaffected samples tested soon after one containing TCA; "fatigue" refers to failure to perceive TCA present in subsequent samples after testing of TCA-affected samples (Frijters and Bemelmans, 1977; Griffiths, 1974; Guadagni et al., 1963; Maarse et al., 1988). These phenomena can persist for minutes to hours after a sensory test, and can result in false positives, failure to detect differences between samples, or even false negatives. Interestingly, even the samples rated "good" by industry and the control sample, all of which had relatively good expert sensory scores, contained a detectable concentration of TCA.

In the soil challenge trials, initial analysis of the four soils showed that TCA was not detectable at the start of the trials. Among the factors investigated, five were found to have a significant effect on the level of TCA evolved from the soils after incubation; i.e., the main effects of preheating, analytical method, soil type, pesticide, and a two-way interaction between pesticide and soil type (Table 1). Although TCA was 66\% higher in soils containing tubers compared with soils without tubers (46.7 $\mathrm{mol} \cdot \mathrm{kg}^{-1}$ vs. $28.2 \mathrm{~mol} \cdot \mathrm{kg}^{-1}$ respectively), the difference was not significant $(P=0.084$; Table 1$)$. Replication of the main plot factors was limited because of operational aspects of the design. Further research with greater replication and investigation of factors such as other OFO compounds and their interaction could help to determine the importance of potato tubers in TCA production. 
Table 1. Partitioning of sources of variation for 2,4,6-trichloroanisole [TCA $\left.\left(\log _{10} \mathrm{~mol} \cdot \mathrm{kg}^{-1}\right)\right]$ released from pesticide-treated soils after incubation, after pooling of nonsignificant random effects and interactive effects involving the analytical method into the residual.

\begin{tabular}{|c|c|c|c|c|}
\hline Source of variation & $\begin{array}{l}\text { Samples } \\
\text { (n) }\end{array}$ & $d f$ & $\begin{array}{c}\text { Mean } \\
\text { square }\end{array}$ & $\begin{array}{c}P \\
\text { value }\end{array}$ \\
\hline Heat $^{z}$ & 64 & 1 & 2.655 & 0.044 \\
\hline Potato $^{y}$ & 64 & 1 & 1.535 & 0.084 \\
\hline Heat $\times$ potato & 32 & 1 & 0.044 & 0.69 \\
\hline Analytical method ${ }^{\mathrm{x}}$ & 64 & 1 & 4.826 & $\mathbf{0 . 0 2 0}$ \\
\hline Error (a) & & 3 & 0.236 & \\
\hline Soil type ${ }^{w}$ & 64 & 1 & 1.052 & $\mathbf{0 . 0 3 8}$ \\
\hline Pesticide $^{v}$ & 16 & 7 & 0.931 & 0.001 \\
\hline Soil type $\times$ pesticide & 8 & 7 & 0.499 & $\mathbf{0 . 0 5 4}$ \\
\hline Soil type $\times$ heat & 32 & 1 & 0.001 & 0.950 \\
\hline Pesticide $\times$ heat & 8 & 7 & 0.189 & 0.583 \\
\hline Soil type $\times$ potato & 32 & 1 & 0.044 & 0.667 \\
\hline Pesticide $\mathrm{x}$ Potato & 8 & 7 & 0.100 & 0.883 \\
\hline Soil type $\times$ pesticide $\times$ heat & 4 & 7 & 0.319 & 0.238 \\
\hline Soil type $\times$ pesticide $\times$ potato & 4 & 7 & 0.033 & 0.995 \\
\hline Soil type $\times$ heat $\times$ potato & 16 & 1 & 0.053 & 0.636 \\
\hline Pesticide $\times$ heat $\times$ potato & 4 & 7 & 0.154 & 0.705 \\
\hline Soil type $\times$ pesticide $\times$ heat $\times$ potato & 2 & 7 & 0.037 & 0.992 \\
\hline Residual & & 60 & 0.234 & \\
\hline
\end{tabular}

Bold type indicates sources of variation in which differences are significant at $P \leq 0.05$.


growth room.

yPotato tubers placed in the soil.

${ }^{\mathrm{x}}$ Analysis method 1 or analysis method 2 .

wProduction soils from which off-flavor potatoes were produced, or idle soils that had not received agricultural inputs for a minimum of 8 years.

${ }^{\mathrm{v}}$ Addition of one of six pesticides, all six, or none.

The quantity of TCA measured was greater in analysis method 2 than in analysis method $1\left(56.7 \mathrm{~mol} \cdot \mathrm{kg}^{-1}\right.$ vs. 23.2 mol. $\mathrm{kg}^{-1}$ respectively; $\left.P=0.020\right)$. This difference can be attributed to the extraction technique and analytical apparatus used. The ECD used in analysis method 2 provides higher quantitative precision than the GC-MS method used in analysis method 1. However, despite the different range of quantities of TCA measured by the two analysis methods, there were no significant interactions of analysis method with the other factors, indicating the relative quantities of TCA measured by the two methods were similar; hence the interaction terms were deleted from the ANOVA model (Table 1). Therefore, the data from all four trials (i.e., both analysis methods) have been combined in the following results and discussions because it is reasonable to consider all four trials as repetitions of the same study.

Almost twice as much TCA was released from soils that were preheated just before incubation than from soils that were not preheated $\left(50.6 \mathrm{~mol} \cdot \mathrm{kg}^{-1}\right.$ vs. $26.1 \mathrm{~mol} \cdot \mathrm{kg}^{-1}$ respectively; $P=0.044$ ). This suggests heat was an important factor in the production of TCA in soils. Many of the organisms that are known to convert precursors to TCA are xerophilic (Neidleman and Geigert, 1986). The uncharacteristically hot weather that occurred during the 2001 growing season may have increased the quantity of TCA produced in the field soils by favoring the activity of xerophiles, which in turn may have contaminated the growing potato tubers to an organoleptically detectable con- centration. It should be noted that although the hot and dry conditions experienced during 2001 were unusual for Nova Scotia, such conditions are not uncommon in many potato production areas around the world.

Soil type affected the TCA values. "Production" soils released more TCA than "idle" soils $\left(44.7 \mathrm{~mol} \cdot \mathrm{kg}^{-1}\right.$ vs. 29.4 mol $\cdot \mathrm{kg}^{-1}$ respectively; $P=0.038$ ). This may be attributable to residual pesticides in the "production" soil from applications during the preceding growing seasons, additional pesticides applied during the 2001 growing season, or the presence of adapted soil microorganisms selected through agricultural production practices. However, TCA was detected from all soils after incubation (Table 2), including the "idle" soils that had not recently received any agricultural inputs including pesticides. This suggests that all soils contained the capacity to produce TCA that could affect potatoes and other root or tuber crops grown in those fields. This, in turn, may explain why a low concentration of TCA was found analytically in potatoes that were judged organoleptically to be unaffected by the musty OFO (Fig. 2).

There was a significant main effect of pesticide treatment on TCA values (Table 1). The quantity of TCA released from soils (mean of both soil types) was much higher after incubation with $\gamma$-CHC than any of the other five pesticides applied singly or all six together (Table 2). Fludioxonil applied singly and all six pesticides together also had higher TCA values than the control.

The effect of pesticide treatment on TCA released from the soils after incubation was influenced by soil type (Table 1), particularly for linuron (Table 2). The same or higher quantities of TCA were released from "production" soils than from the "idle" soils subjected to the same pesticide treatment. Within the "idle" soil type, the quantities of TCA released when pesticides were applied either singly, except for $\gamma-\mathrm{CHC}$, or all six together were not significantly different from each other or from the control (Table 2). Within the "production" soil type, the

Table 2. Quantity of 2, 4, 6-trichloroanisole (TCA) measured from "idle" and "production" soils and their mean after incubation for 2 weeks at $22{ }^{\circ} \mathrm{C}$ day $/ 18{ }^{\circ} \mathrm{C}$ night with pesticides applied singly or together.

\begin{tabular}{llccc}
\hline & \multicolumn{3}{c}{ TCA $\left(\log _{10} \mathrm{~mol} \cdot \mathrm{kg}^{-1}\right)$} & \\
\cline { 2 - 4 } Pesticide & $\begin{array}{c}\text { "Idle" } \\
\text { soils }^{\mathrm{z}}\end{array}$ & $\begin{array}{c}\text { "Production" } \\
\text { soils }^{\mathrm{y}}\end{array}$ & $\begin{array}{c}\text { Mean of } \\
\text { both soils }\end{array}$ & $\begin{array}{c}\text { Increase from } \\
\text { control }(\%)^{\mathrm{x}}\end{array}$ \\
\hline Control & 1.38 & 1.11 & 1.25 & \\
Chlorothalonil & 1.38 & 1.62 & 1.50 & 76 \\
Chlorpyrifos & 1.26 & 1.66 & 1.46 & 62 \\
Fludioxonil & 1.40 & 1.83 & 1.61 & 131 \\
Imidacloprid & 1.40 & 1.52 & 1.46 & 63 \\
Linuron & $1.06^{\mathrm{w}}$ & $1.81^{\mathrm{w}}$ & 1.43 & 53 \\
$\gamma$-CHC & 2.19 & 1.92 & 2.06 & 541 \\
All six pesticides & 1.69 & 1.72 & 1.71 & 186 \\
Mean & 1.47 & 1.65 & 1.56 & \\
SE & \multicolumn{5}{c}{0.1711} & 0.1210 & \\
\hline
\end{tabular}

${ }^{\mathrm{z} F a r m}$ soils that had received no agricultural inputs for at least 8 years before the reported research.

"Farm soils that had produced potatoes affected by a "musty" "off" flavor/"off" odor in the preceding growing season, and had been treated with $\gamma$-cyclohexane hexachloride $(\gamma-\mathrm{CHC})$ at the beginning of that growing season.

${ }^{\mathrm{x}}$ Comparison among means of both soils, after back-transformation of values from $\log _{10}$ used in the statistical analysis.

${ }^{\text {w }}$ Significant interaction $(P \leqq 0.05)$ between linuron and soil type. 
quantities of TCA released when pesticides were applied either singly, except for imidacloprid applied alone, or all six combined were higher than the control. Although $\gamma$-CHC applied alone had the highest TCA among the "production" soils, it was not significantly higher than the other pesticide treatments.

Because the soil treatment containing all six pesticides included $\gamma-\mathrm{CHC}$, this treatment could be expected to have TCA values similar to or higher than $\gamma$-CHC alone. This was observed in the "production" soils, but in "idle" soils the six pesticides combined treatment released less TCA than $\gamma-\mathrm{CHC}$ alone (Table 2). Additional study would be needed to determine the cause for this observation, but it may possibly be the result of the presence of residual pesticides and/or adapted strains of microflora in the "production" soils.

As a consequence of these research results, the $\gamma$-CHC registrant has amended the pesticide label to allow application only to fields that will not be used for potato production for 3 years. In addition, potato producers in the Annapolis Valley, Nova Scotia, have turned to alternative methods to control wireworm problems in the soil (T. Troop, pers. comm.), including cultural methods and a temporary registration for phorate [Thimet 15G (15\% a.i.); Amvac Chemical Corp., Toronto]. Since these measures were implemented in 2002, no repetitions of the "musty" OFO have been reported, providing further evidence that $\gamma$-CHC was a principal factor, in combination with unusually hot soil temperatures, in the production of TCA-based "musty" OFO in the 2001 crop. This study has identified influences of high soil temperature and pesticides other than $\gamma$-CHC on the release of TCA from soil, and the presence of TCA in tubers from fields that had not been treated with $\gamma$-CHC. These factors are of importance to the potato industry.

\section{Literature Cited}

Alzaga, R., L. Ortiz, F. Sanchez-Baeza, M.P. Marco, and J.M. Bayona. 2003. Accurate determination of 2,4,6-trichloroanisole in wines at low parts per trillion by solid-phase microextraction followed by GC-ECD. J. Agr. Food Chem. 51:3509-3514.

Aung, L.H., J.L. Smilanick, P.V. Vail, P.L. Hartsell, and E. Gomez. 1996. Investigations into the origins of chloroanisoles causing musty off-flavour of raisins. J. Agr. Food Chem. 44:3294-3296.

Busser, H.-R., C. Zanier, and H. Tanner. 1982. Identification of 2,4,6trichloroanisole as a potent compound causing cork taint in wine. J. Agr. Food Chem. 30:359-362.

Buttery, R.G. and L.C. Ling. 1973. Earthy aroma of potatoes. J. Agr. Food Chem. 21:745-746.

Buttery, R.G., R.M. Seifert, and L.C. Ling. 1970. Characterization of some volatile potato components. J. Agr. Food Chem. 18:538-539.

Coleman, E.C., C.-T. Ho, and S.S. Chang. 1981. Isolation and characterization of volatile compounds from baked potatoes. J. Agr. Food Chem. 29:42-48.

Curtis, R.F., C. Dennis, J.M. Gee, M.G. Gee, N.M. Griffiths, D.G. Land, J.L. Peel, and D. Robinson. 1974. Chloroanisoles as a cause of musty taint in chickens and their microbiological formation from chloroanisoles on broiler house litter. J. Sci. Food Agr. 25:811-828. Dawson, E.H., G.L. Gilpin, M.E. Kirkpatrick, and C.A. Weigel. 1953. Flavor of selected vegetables grown in soil treated with isomers of benzene hexachloride. Agr. Food Chem. 1:399-403.

Elvers, B., S. Hawkins, M. Ravenscroft, and G. Schultz (eds.). 1985. Ullman's encyclopedia of industrial chemistry. 5th ed. VCH Publishers, Deerfield Beach, Fla.

Engst, R., R.M. Macholz, and M. Kujawa. 1977. The metabolization of lindane in a culture of mould and the degradation scheme of lindane. Chemosphere 6:401-418.
Evans, T.J., C.E. Butzke, and S.E. Ebeler. 1997. Analysis of 2,4,6trichloroanisole in wines using solid-phase microextraction coupled to gas chromatography-mass spectrometry. J. Chromatogr. A 786:293-298.

Ezquerro, O. and M.T. Tena. 2005. Determination of odour-causing volatile organic compounds in cork stoppers by multiple headspace solid-phase microextraction. J. Chromatogr. A 1068:201-218.

Frijters, J.E.R. and J.M.H. Bemelmans. 1977. Flavour sensitivity for chloroanisoles in coagulated egg yolk. J. Food Sci. 42:1122-1123.

Greenwood, M.L. and J.M. Tice. 1949. Palatability tests on potatoes grown in soil treated with the insecticides benzene hexachloride, chlordane and chlorinated camphene. J. Agr. Res. 78:477-482.

Griffiths, N.M. 1974. Sensory properties of the chloroanisoles. Chem. Senses Flavor 1:187-195.

Guadagni, D.G., R.G. Buttery, and S. Okano. 1963. Odour thresholds of some organic compounds associated with food flavours. J. Sci. Food Agr. 14:761-765.

Health Canada. 2005. Food and drug regulations, part b, division 15, adulteration of food (clause B.15.002), 2 Dec. 2005. Health Canada, Ottawa, Canada.

Hill, J.L., A.D. Hocking, and F.B. Whitfield. 1995. The role of fungi in the production of chloroanisoles in general purpose freight containers. Food Chem. 54:161-166.

Holmstrom, D.A. and B.L. Thompson. 1989. Soils of the Annapolis Valley area of Nova Scotia. Nova Scotia soil survey report no. 22. Agriculture Development Branch, Agriculture Canada, Ottawa, Canada.

International Organization for Standardization. 1993. Sensory analysis: General guidance for the selection, training and monitoring of assessors, part 2: Experts. Document 8586-1. International Organization for Standardization, American National Standards Institute, New York

Land, D.G., G.G. Malcolm, J.M. Gee, and C.A. Spinks. 1975. 2,4,6Trichloroanisole in broiler house litter: A further cause of musty taint in chickens. J. Sci. Food Agr. 26:1585-1591.

Langille, D.R. 1986. Soils of the Kentville research station and Sheffield farm. Nova Scotia soil survey report no. 21. Research Branch, Agriculture Canada, Ottawa, Canada.

Langille, D.R., K.T. Webb, and T.J. Soley. 1993. Supplement to soils of the Annapolis Valley area of Nova Scotia, Nova Scotia soil survey report no. 26. Agri-Food Development Branch, Agriculture Canada, Ottawa, Canada.

Liardon, R., J.C. Spadone, N. Braendlin, and E. Dentan. 1990. Multidisciplinary study of Rio flavour in Brazilian green coffee. p. 117-126. In: Treizième Colloque Scientifique sur le café: Paipa, Colombia, 21-25 Aug. 1989. Association Scientifique International du Café, Paris, France.

Maarse, H., L.M. Nijssen, and S.A.G.F. Angelino. 1988. Halogenated phenols and chloroanisoles: Occurrence, formation and prevention, p. 43-61. In: M. Rothe (ed.). Characterization, production and application of food flavours. Akademic Verlag, Berlin.

Mazza, G. and E.M. Pietrzak. 1990. Headspace volatiles and sensory characteristics of earthy, musty flavoured potatoes. Food Chem. 36:97-112.

Neidleman, S.L. and J. Geigert. 1986. Halometabolites and their sources, p. 13-45. In: Biohalogenation: Principles, basic roles and applications. Ellis Horwood, Chichester, UK.

Nijssen, B. 1991. Off-flavors, p. 689-735. In: B. Nijssen and H. Maarse (eds.). Volatile compounds in foods and beverages. Marcel Dekker, New York.

Nursten, H.E. and M.R. Sheen. 1974. Volatile flavour components of cooked potato. J. Sci. Food Agr. 25:643-663.

Payne, R.W. (ed). 2005. The guide to GenStat release 8: Statistics. VSN International, Oxford, UK.

Reilly, T.I. and R.K. York. 2001. Guidance on sensory testing and monitoring of seafood for presence of petroleum taint following an oil spill. National Oceanographic and Atmospheric Administration Technical Memorandum NOS OR\&R 9. NOAA, Seattle, Wash. 
Reynolds, H., G.L. Gilpin, and I. Hornstein. 1953. Palatability and chemical studies on peanuts grown in rotation with cotton dusted with insecticides containing benzene hexachloride. J. Agr Food Chem. 1:772-776.

Riu, M., M. Mestres, O. Busto, and J. Guasch. 2002. Determination of 2,4,6-trichloroanisole in wines by headspace solid-phase microextraction and gas chromatography-electron-capture detection. J. Chromatogr. A 977:1-8.

Spadone, J.-C., G. Takeoka, and R. Liardon. 1990. Analytical investigation of Rio off-flavor in green coffee. J. Agr. Food Chem. 38:226-233.

Supelco. 1998. Solid phase microextraction of odors in drinking water, for analysis by GC/MS. Application note T398147. Supelco/SigmaAldrich, Bellefonte, $\mathrm{Pa}$.
Tindale, C.R. 1987. Shipping container floors: A potential source of chloroanisole contamination in foods. Chem. Ind. 6 Jul.:458-459.

Tindale, C.R., F.B. Whitfield, S.D. Levingston, and T.H.L. Nguyen. 1989. Fungi isolated from packaging materials: Their roles in the production of 2,4,6-trichloroanisole. J. Sci. Food Agr. 49:437-447. Whitfield, F.B. 1986. Food off-flavors: Cause and effect, p. 249-273. In: G.G. Birch and M.G. Lindley (eds.). Developments in food flavors. Elsevier Applied Science, New York.

Whitfield, F.B., T.H.L. Nguyen, K.J. Shaw, J.H. Last, and G. Stanley. 1985. Contamination of dried fruit by 2,4,6-trichloroanisole absorbed from packaging materials. Chem. Ind. (London) 661-662.

Wolfenbarger, D.O., P. Decker, and W.A. Rawlins. 1948. Off-flavor of potato tubers produced by benzene hexachloride used for wireworm control. Amer. Potato J. 25:413-417. 